\title{
PEMANFAATAN FOOTSANITIZER SPRAY DAPAT MENUMBUHKAN JIWA WIRAUSAHA BAGI SISWA SMK BISMA DI KERSANA KABUPATEN BREBES
}

\author{
Aldi Budi Riyanta ${ }^{1}$, Anggy Rima Putri ${ }^{2}$, Agus Susanto ${ }^{3}$ \\ ${ }^{\mathbf{1}, 2,3}$ Prodi DIII Farmasi Politeknik Harapan Bersama Tegal \\ Jl. Mataram No. 9 Pesurungan Lor Kota Tegal Telp. (0283) 352000 \\ Email: ${ }^{1}$ aldi.kimor@gmail.com, ${ }^{2}$ Self6ie_11@gmail.com, ${ }^{3}$ Agussus@yahoo.com
}

\begin{abstract}
Abstrak
SMK Bisma berpotensi sebagai unggulan dibidang pendidikan dan kesehatan. Kesehatan kaki menjadi masalah penting yang mesti diperhatikan oleh semua sektor mulai dari lingkup keluarga, guru, staff, dan siswa SMK Bisma itu sendiri. Cita rasa dan aroma kopi sudah banyak digunakan untuk penghilang bau. Sehingga perlu dilakukan inovasi mengenai pembuatan produk footsanitizer dari kopi sebagai penghilang bau kaki. Pembuatan footsanitizer dikalangan Siswa SMK seperti di SMK BISMA menjadi modal enterpreuner dan wirausaha. Untuk itu, siswa dibekali keterampilan membuat produk footsnitizer. Metode pembuatan yang digunakan dengan mencampur seluruh bahan dan kemudian menambahkan kopi sebagai penghilang bau kakinya. Metode ini kemudian sebagai modal pelatihan bagi siswa SMK Bisma dan memberikan respon yang posistif dari siswa dalam rangka mengikuti kegiatan ini.
\end{abstract}

Kata kunci: SMK Bisma, Footsanitizer, Kopi

\section{PENDAHULUAN}

SMK Bisma merupakan salah satu SMK yang cukup potensial, baik dari segi pendidikan, kesehatan, lingkungan, ekonomi bagi masyarakatnya (guru, staff, dan siswa). Namun dari ke- 4 bidang tesebut masih terdapat berbagai permasalahan yang menjadi tugas dan tanggung jawab kita bersama terutama bidang kesehatan dan ekonomi di SMK Bisma tersebut.

Masalah kesehatan merupakan salah satu hal penting yang harus diperhatikan oleh semua sektor mulai dari lingkup keluarga, guru, staff, dan siswa SMK Bisma itu sendiri. Kaki adalah salah satu bagian tubuh yang sering berkeringat. Apalagi jika kaki hampir selalu ditutupi dengan sepatu sepanjang hari di cuaca yang panas, sudah pasti akan menimbulkan bau yang tidak sedap menempel di kaki. Bau kaki disebabkan oleh penumpukan bakteri yang berkembang biak pada kaki yang lembab. Bakteri-bakteri tersebut juga memakan keringat di kaki dan menghasilkan asam yang memiliki bau tidak sedap. Bau kaki yang menyengat menjadikan orang menjadi tidak nyaman dalam bekerja dan beraktifitas. Sehingga berbagai upaya dilakukan untuk mencegahnya. Namun kenyataannya meskipun sarana kesehatan telah 
tersedia, siswa masih kurang sadar akan kesehatan terutama untuk kesehatan kelembapan kaki. Pengetahuan akan kesehatan ini yang masih kurang diperhatikan. Upaya pencegahan yang sering dilakukan yaitu mencuci kaki dengan sabun, mengeringkan kaki sebelum memakai sepatu hingga menggunakan bedak tabur ${ }^{6}$. Namun, upaya ini dirasa kurang praktis dan dan perlu adanya upaya lain sebagai tindakan pencegahan. Upaya yang dapat dilakukan dengan menggunakan foot sanitizer.

Melihat siswa, guru dan staf ditingkat sekolah menengah yang sebagian besar banyak mengkonsumsi kopi, dimana Kopi (Coffea sp) merupakan tanaman yang sering digunakan sebagai bahan minuman seduh $^{3}$. Kopi memiliki cita rasa dan aroma yang khas sehingga banyak digunakan untuk penghilang bau ${ }^{8}$. Kopi memiliki kandungan kafein sebesar 1,06 \%, menurut Hayati dkk, (2012). Kafein merupakan salah satu zat yang dimanfaatkan dalam bentuk obat maupun dalam bentuk makanan atau minuman sehari-hari yang bisa didapatkan dengan mudah, misalnya saja, pada kopi, cokelat, berbagai teh maupun soft-drink. Kafein akan membuat tubuh menjadi lebih segar dan mampu meningkatkan metabolisme karena merangsang kelenjar adrenal $^{7}$. Meskipun, Kandungan kafein pada kopi belum bisa menghambat efek antimikroba ${ }^{2}$. Kopi dapat menghilangkan pusing kepala karena aromanya yang khas ${ }^{4}$. Kandungan kafein pada kopi akan mempengaruhi kerja adenosine sehingga tubuh akan terasa lebih segar ${ }^{1}$. Sehingga kopi cocok digunakan sebagai bahan aktif flavor pada pembuatan foot sanitizer.

Foot sanitizer belum banyak dikenal dan masih jarang penggunaannya. Foot sanitizer dasarnya sama dengan prinsip hand-sanitizer. Foot sanitizer mengandung etanol 62\%, pelembut, dan pelembab. Kandungan bahan aktifnya adalah alkohol yang memiliki efektivitas paling tinggi terhadap virus, bakteri, dan jamur juga tidak menimbulkan resistensi pada bakteri. Alkohol sendiri dapat membuat kaki menjadi kering. Sehingga foot sanitizer harus dilengkapi dengan moisturizer dan emolient, yang menjaga kaki tetap lembut, tidak menjadi kering, tidak seperti larutan alkohol murni yang dapat menyebabkan dehidrasi pada kulit. Foot sanitizer perlu dilakukan penambahan bahan aktif mengingat penggunaan berlebih alkohol sebagai bahan utamanya akan menimbulkan efek iritan. Bahan aktif yang dapat digunakan berupa rempah-rempah.

\section{METODE}

Identifikasi permasalahan yang muncul di SMK Bisma dengan adanya kegiatan belajar mengajar dalam waktu yang lama menjadi suatu permasalahan penggunaan sepatu yang nantinya akan menimbulkan bau kaki. Permasalahan tersebut yang selanjutnya dikaji dan dicarikan solusi. Metode pendekatan untuk dapat menyelesaikan permasalahan dalam kegiatan ini menggunakan metode Participatory Action Research (PAR). Solusi yang 
ditawarkan pada kegiatan pengabdian pada masyarakat ini berupa pemberian penyuluhan dengan materi mengenai pembuatan footsanitzer dan kemudian diadakan pelatihannya. Bahan-bahan pembuatan footsanitizer dapat dengan mudah ditemukan di toko kimia terdekat. Bahan dasar pembuatan footsanitizer meliputi kopi, alkohol 70\%, pengawet, gliserin.

\section{HASIL DAN PEMBAHASAN}

Pembuatan ekstrak biji kopi, cairan pemaserasi digunakan etanol 70\%. Maserasi dilakukan dengan merendam serbuk biji kopi sebanyak 100 gram dalam 1 liter etanol 70\%, kemudian dikocok selama 6 jam menggunakan shaker dan didiamkan selama 18 jam. Maserat disaring menggunakan penyaring vakum kemudian dipisahkan dari ampasnya. Ampas dimaserasi ulang dan disaring kembali sebanyak 2 kali dengan cara yang sama. Semua maserat dikumpulkan dipekatkan dengan rotary evaporator suhu $60^{\circ} \mathrm{C}$ dengan kecepatan 50 rpm.

a) Pembuatan Spray Foot sanitizer

1) Menyiapkan dan menimbang/mengukur masing-masing bahan.

2) Setengah bagian alkohol $70 \%$ ditambahkan ke dalam ekstrak.

3) Menambahkan methyl paraben dan gliserin secukupnya sebagai pelembut.

4) Aduk rata dan tambahkan sisa alkohol dan sedikit air untuk kekentalan yang diinginkan. Lalu masukkan kedalam botol spray kecil untuk penyimpanan.

Tabel 1. Formula Footsanitizer

\begin{tabular}{|c|c|}
\hline BAHAN & FORMULA (\%) \\
\hline Ekstrak Biji Kopi & 35 \\
\hline \multicolumn{2}{|l|}{ Add: } \\
\hline Methyl Paraben & 0,02 \\
\hline Gliserin & 10 \\
\hline Ethanol 70\% & Ad 100 \\
\hline
\end{tabular}

Kegiatan ini dilanjutkan dengan pemaparan materi mengenai pentingnya kesehatan kaki dan bagaimana bau kaki itu terjadi. Bau kaki terjadi karena adanya kuman yang ada disekitar kaki hingga menimbulkan bau kaki. Salah satu pencegahannay dapat digunakan berbagai cara seperti mencuci kaki dengan sabun secara rutin hingga merendam kaki dengan cairan tertentu. Namun cara yang efektif dan praktis dengan menggunakan spray foot sanitizer. Kandungan kopi didalam sediaan efektif mengurangi bau kaki. Kegiatan ini dipraktekkan oleh siswa didampingi narasumber. Siswa menilai kegiatan ini sangat 
bermanfaat karena siswa dilatih membuat sediaan foot sanitizer sebagai bekal keterampilannya, siswa juga bertambah pengetahuannya mengenai pentingnya menjaga kesehatan kaki.
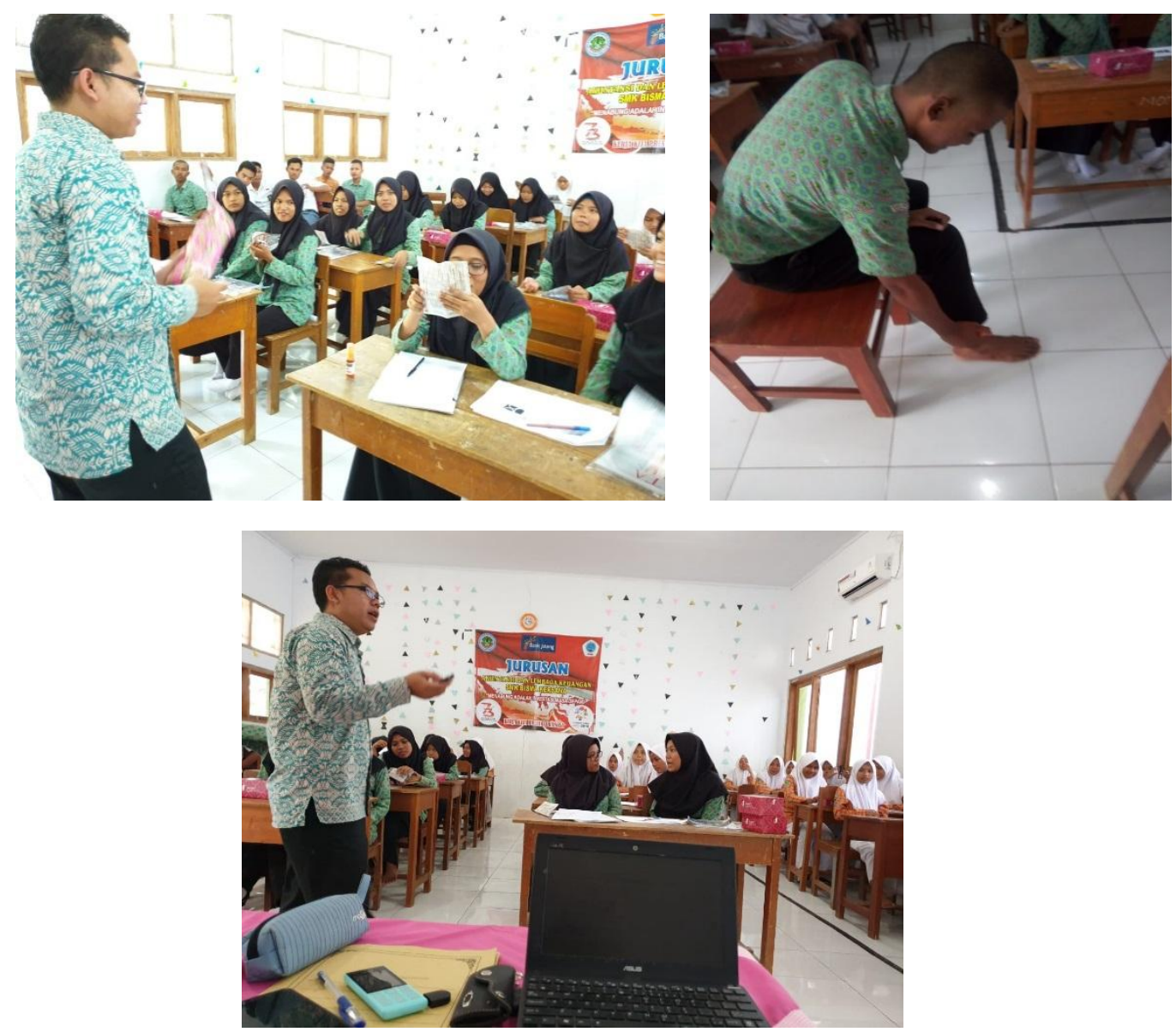

Gambar 1. Kegiatan pelatihan pembuatan foot sanitizer dari biji kopi

\section{KESIMPULAN}

Kegiatan pelatihan pembuatan spray foot sanitizer dari biji kopi dapat dijadikan sebagai bekal pengetahuan dan keterampilan bagi Siswa dan Siswi SMK Bisma sebagai modal berwirausaha.

\section{SARAN}

Kegiatan ini perlu dilakukan secara kesinambungan untuk memantau potensi wirausaha yang dilakukan peserta setelah mengikuti pelatihan. 


\section{UCAPAN TERIMA KASIH}

Peneliti mengucapkan terima kasih kepada Politeknik Harapan Bersama Tegal melalui Unit P3M atas biaya pengabdian Institusi yang diberikan dengan SK Direktur 038.05/PHB/V/2019 Tanggal 17 Mei 2019 dengan nomor kontrak 019.16/P3M.PHB/V/2019.

\section{DAFTAR PUSTAKA}

[1] Depkes RI. 2006.” Melawan dampak negatif kafein”. Dalam Intisari. Departemen Kesehatan Republik Indonesia. www.depkes. go.id. Akses Jumat, 10 Februari 2017

[2] Haryanto, F. 1986. Sifat dan Aktifitas Antibakteri Ekstrak Bubuk Kopi (Coffea robusta).

[3] Hayati, R., Marliah, A., Rosita., M., 2012. "Sifat Kimia Dan Evaluasi Sensori Bubuk Kopi Arabika" Prodi Agroteknologi Fakultas Pertanian Universitas Syiah Kuala Darussalam Banda Aceh J. Floratek 7: pp 66 - 75

[4] Kadapi, M dan Rahayu., 2015. "Aktivitas Antioksidan Kopi Biji Rambutan Non Kafein Dengan Variasi Perbandingan Komposisi Beras Hitam Yang Berbeda". Program Pendidikan Biologi, Fakultas Keguruan dan Ilmu Pendidikan, Universitas Muhammadiyah Surakarta

[5] Mulato, S., 2002. Simposium Kopi 2002 dengan tema Mewujudkan perkopian Nasional Yang Tangguh melalui Diversifikasi Usaha Berwawasan Lingkungan dalam Pengembangan Industri Kopi Bubuk Skala Kecil Untuk Meningkatkan Nilai Tambah Usaha Tani Kopi Rakyat. Denpasar : 16 - 17 Oktober 2002. Pusat Penelitian Kopi dan Kakao Indonesia.

[6] Sentika, B., 2009. "Hilangkan Bau Kaki” Artikel MyCIC STMIK CIC. Akses 7 Februari 2017 pukul 12.00 WIB

[7] Widyotomo, Sukrisno dan Mulato, S., 2007. "Kafein : Senyawa Penting Pada Biji Kopi”. Jurnal Warta Pusat Penelitian Kopi dan Kakao Indonesia 23(1) pp 44-50

[8] Farida, A., Evi, R., Kumoro AC., 2013. Penurunan Kadar kafein dan asam Total pada biji kopi robusta menggunakan teknologi fermentasi anaerob fakultatif dengan mikroba Nopkor MZ-15. Jurnal Teknologi Kimia dan Industri Vol.2 No.3 :70-75 